\title{
Fluvial Dynamic in Oued El Abid Basin: Monitoring and Quantification at an Upstream River Section in Bin El Ouidane Dam - 2016 / 2017-(Central High Atlas / Morocco)
}

\author{
Hasan Ouakhir ${ }^{1,2}$, Mohamed El Ghachi ${ }^{1,2}$, Mimoun Goumih ${ }^{1,2}$, Lamti Hamid ${ }^{1,2}$ \\ ${ }^{1}$ Department of Geography, Faculty of Letters and Human Sciences, Sultan Moulay Slimane University, Beni Mellal, Morocco \\ ${ }^{2}$ Laboratory Dynamic of Landscapes, Risks and Heritage, Beni Mellal, Morocco
}

\section{Email address:}

wa5irhassan@gmail.com (H. Ouakhir), elghachi_mohamed@yahoo.fr (M. El Ghachi), mimoungoumih89@gmail.com (M. Goumih), hmdlameti@gmail.com (L. Hamid)

${ }^{*}$ Corresponding author

\section{To cite this article:}

Hasan Ouakhir, Mohamed El Ghachi, Mimoun Goumih, Lamti Hamid. Fluvial Dynamic in Oued El Abid Basin: Monitoring and Quantification at an Upstream River Section in Bin El Ouidane Dam - 2016 / 2017-(Central High Atlas / Morocco). American Journal of Mechanics and Applications. Vol. 8, No. 4, 2020, pp. 47-58. doi: 10.11648/j.ajma.20200804.11

Received: June 19, 2020; Accepted: July 13, 2020; Published: December 31, 2020

\begin{abstract}
Soil erosion is a complex phenomenon, which particularly influences water and soil potentials. In the mountainous areas, water erosion phenomenon is accentuated by steep slopes and the degradation of vegetation cover. soil erosion is a worldwide phenomenon threatening the social, environmental and the economic life. In Morocco, fluvial erosion is one of the issues that affects the national territory. The location of Morocco, in the south of Mediterranean region provides remarkable climatic and ecological diversity. Located in the Moroccan High Atlas, El Abid basin belongs to a semi-arid climate. It is characterized by steep slopes and abundant precipitation which gives mountain flows a torrential characteristic. The discharge can reach very important values. Long term hydrological records for El Abid river (1970-2017) demonstrate the annual and seasonal variability in discharge with winter and spring periods typically representing $87 \%$ of the flow. Soils are increasingly degraded and sediments from erosion contribute to the siltation of Bin Ouidane dam. This siltation is the result of deposits of soil erosion. During flood periods this dam is silted by the sediment transport. This article aims to quantify the rate of fluvial erosion in the upstream section of the Bin El Ouidane dam. Then, to understand the process of river dynamics and its impact on silting issue, through the application of an approach technique based on the realization of several cross profiles, and with a main objective being to compare the results of the river dynamics of the two campaigns during 2016 and 2017. In addition, the measurements taken were supplemented by qualitative observations, particularly during the baseflow of the river, the incision of the bed (or stream), the regressive erosion of the banks, the apparent nature of the substrate, and certain anthropogenic actions.
\end{abstract}

Keywords: Upstream Part of Bin El Ouidane Dam, Fluvial Dynamic, Water Erosion, Cross Section, Quantification 2016-2017

\section{Introduction}

Water erosion is a particularly important issue, especially in the temperate and semi-arid Mediterranean area [1]. It is a dynamic process of detaching, transporting and depositing soil particles under the effect of the kinetic energy of water. Soil loss causes widespread adverse influences with different intensities depending on the environment biophysical characteristics and threats human sustainability [2]. The effects of this phenomenon are not limited only to the reduction of agricultural land productivity [3] but they also affect the quantity and quality of available water by accelerating the rate of siltation of reservoirs and reducing the production of electricity [4]. In Morocco, $40 \%$ of 1 and cover is affected by water erosion [5] In some parts of the Rif in northern Morocco, erosion rates sometimes reach 30 to 60 
$\mathrm{t} / \mathrm{ha} / \mathrm{yr}[6,7]$ and get to $2000 \mathrm{t} / \mathrm{km}^{2} / \mathrm{yr}$ for the central and western Rif [8]. In the Middle and High Atlas, the annual averages ranged from 500 to $1000 \mathrm{t} / \mathrm{km}^{2} /$ year and from 1000 to $2000 \mathrm{t} / \mathrm{km}^{2} / \mathrm{yr}$ in the Pre-Rif and the Mediterranean border. Therefore, dams lose their water storage initial capacity due to their siltation which is estimated at $0.5 \%$ by year [9]. The largest Moroccan dams receive each year approximately 50 million tons of sediment [10], which affects their storage capacity and brings about an annual loss of almost 300 million Dirhams. In Central High Atlas, the dynamic of water erosion is accentuated by several factors. Respective influence rain, runoff, roughness and slope of the land depend on the forms of water erosion. Besides, under the effect of climate change, several studies mentioned that most Moroccan dams has been silted for the past 20 years. According to the report published by the International Committee of Large Dams CIGB 2019, more than 50,000 large dams existing in the world with a very large storage capacity, suffer from the problems of siltation, and an average rate of 0.5 to $1 \%$ of their storage capacity is lost each year due to sedimentation. Consequently, the phenomenon of dam's siltation reduces drastically their capacity and their functioning period [11] and minimize the availability for agricultural land irrigation. The main purpose of this study is to constitute a diagnostic of the hydrodynamic functioning of El Abid river in order to provide answers to managers in matters of flooding and morphodynamic issues (erosion, landslide, incision of the beds, etc.). The other objectives are determining which factors control the functioning of El Abid river, then identifying the large fluvial organisms. The highlight of this dynamic at the studied section is done based on two steps: (i) To realize two different sets of cross profiles at 2016 and 2017.(ii) To determine the indicators justifying the fluvial dynamic based on the interpretation of all results, and the data extracted from the field work.

\section{Presentation of Study Area}

The Oued El Abid basin is located between the meridians $6^{\circ} 15^{\prime} \mathrm{W}$ and $6^{\circ} 30^{\prime} \mathrm{W}$, and the parallel $32^{\circ} \mathrm{N}$ and $32^{\circ} 5^{\prime} \mathrm{N}$. The entire basin covers an area of $7975 \mathrm{~km}^{2}$. El Abid river starts flowing from the Masker mountain (Jbel) $(3277 \mathrm{~m})$ with an orientation from $\mathrm{E}$ to $\mathrm{W}$. It extends over the limestone High Atlas, bounded to the $\mathrm{E}$ and $\mathrm{S}$ by a line of High mountain peaks above $3000 \mathrm{~m}$, the highest point at the entire basin is Azourki mountain (Jbel) (3690 m) [12] This basin extends over a large mountainous area with a significant potential of water resources which ensures the supply of Bin El Ouidane dam and the recharge of the aquifers of the Tadla plain in downstream. Administratively, El Abid basin is located in the Region of Beni Mellal Khénifra and extends over several rural communes (Ouaouizeth, Bin El Ouidane, Ait Mazigh, Tagleft, Rfala, Bezou, Tissgui...). Geologically, the basin is a part of the Central High Atlas limestone where the relief is marked by a series of anticlines and synclines, cuted by narrow and deep valleys like Ouaouizerth and Tagleft valley [13]. It develops successively at vast areas corresponding to the marly lands of the Cretaceous and crosses deep gorges, incised in the Jurassic and Lias limestone series [14]. Furthermore, this area is characterized by a lithological diversity, which plays an important role in the velocity of water circulation [15]. The hydrogeological characteristics of the substratum are related to the thickness and the lithology type which determine the storage capacity of water [16]. In the down part of the studied section, Bin El Ouidane dam is, in fact, established in the downstream of incised gorge by El Abid river in a bank of Jurassic limestones, belonging on the southern slope of Djebel Tazerkount, the first link in the Atlas on the edge of the Tadla plain [16].

From a climatic point of view, and due to its geographic location, Morocco is characterized by a strongly contrasted climate, with its rainfall being highly irregular in space and time [17]. El Abid basin as a Mediterranean area characterizes by a semi-arid climate; with dry and humid periods, as well as abrupt spatio-temporal variations in precipitation amounts [12]. The temperature is significantly influenced by the high altitude of the massif. According to the climatic index of Emberger, at Ait Ouchene gauging stations (ABOHER) during the period 1977-2017, El Abid basin has a climatic progression with semi-arid characteristics, and a tendency towards the subhumid [12]. These rainfall characteristics are due to the importance of orographic effects and the geographical distribution of the relief in the basin. The upper part of the basin has a higher altitude exceeding $2500 \mathrm{~m}$, while the down part is characterized by a decrease in relief not exceeding 600 $\mathrm{m}$ [18]. This spatio-temporal variability of rainfall plays a crucial role in the diversity observed in hydrological regimes. The discharge $(\mathrm{Q})$ gradually pass from the regime rain to snow-rain, then snow depending on the change of altitude. The discharge volumes at annual scale are mainly concentrated on the summer period which corresponds to the snowmelt. The flows resulting from this torrential regime accelerating the sediment transport and producing siltation of Bin El Ouidane dam in the downstream (figure 1).

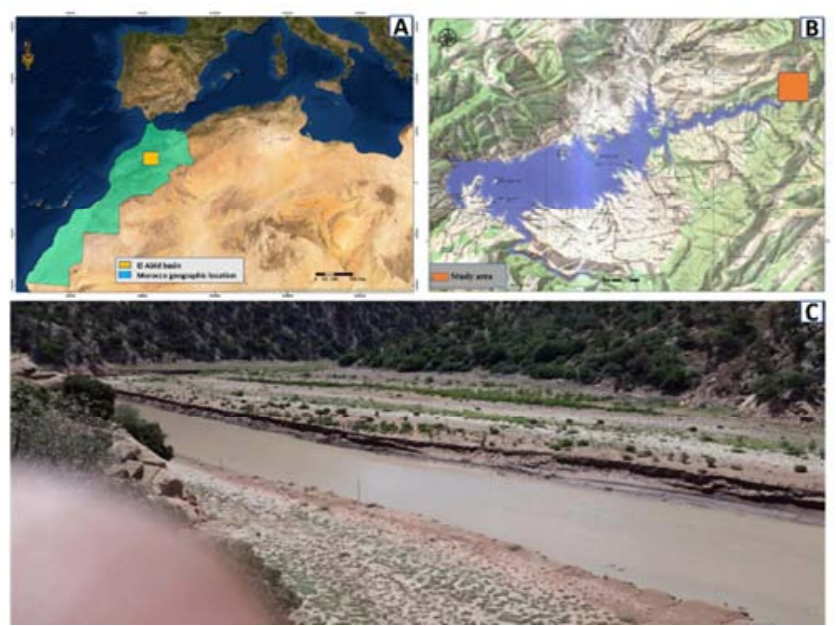

Figure 1. A) Situation of Oum Er Rbia basin in Morocco. B) location of the study area. $C)$ presentation of the studied section. 
El Abid Basin: Hydraulic Installations, Challenges, and Risks

At $24 \mathrm{~km}$ far from Azilal city, Bin El Ouidane dam is located between Oued El Abid and Assif Ahansal. The realization of this dam was for multiple purposes; irrigation, production of electrical energy and drinking water supply.... Its central hydroelectric produces a quarter of the current Moroccan electricity. Its reservoir, with 3800 hectares, is reached an altitude of more than $800 \mathrm{~m}$, which makes it the highest dam in Africa (Regional Investment Center 2015). Currently, Bin El Ouidane dam has been very attractive touristic diversified assets, some of them are known internationally. This dam is also becoming a pole of attraction for tourism projects with activities revolving around water and the lake perimeter. At this water area surrounded by the red slopes of the Ouaouizeght synclinal, several water sports activities take place: jet ski, swimming, windsurfing sailing, besides sport fishing (Blackbass, Pike perch, Pike...) and hunting. Today, this reservoir represents a very diverse biological regional heritage both, ecologically and environmentally.

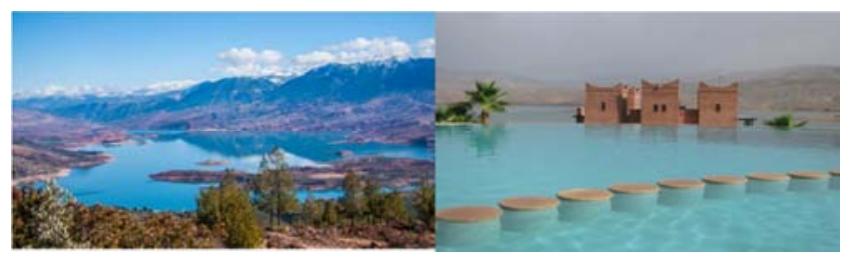

Figure 2. Lake of Bine El Ouidane dam at the outlet of El Abid basin.

According to the specialists from the Ministry of Water, Bine El Ouidane dam has lost its storage capacities by millions of $\mathrm{m} 3$ since its creation. The silting of dams constitutes the most direct consequences which influence negatively these hydraulic dams in space and time.

In studies of fluvial erosion, the main variables to be explained are the river dynamics and the sediment fluxes. In a gradual way, this research aims to understand the processes towards the basin scale, in order to take into account for both water and soil resources and quantify the processes involved which characterize the river dynamic.

\section{Materials and Methods}

\subsection{Materials and Sites Location Criteria}

The topographical approach was carried out by the Differential Global Positioning (GPS, SOKKIA type). This tool is very important in realizing a fine topographic survey. Once the study area has been determined, the location of the sections is presented by marks along the two banks of El Abid river. This latter is changing its trace during to the different seasons along the year, affected by many factors. Bearing in mind that the marked sections must be always perpendicular with the river. At the end, each section has a number and relocated at the field by geographic coordinate System (X, Y and $\mathrm{Z}$ ). The numbers given to these sections are increasing from downstream to upstream part and the direction of each section is started from the left bank to the right bank. Thus, the main objective of these sections was following the evolution of the actual fluvial dynamics in the study section during 2016-2017. The two realized campaigns carried out at the beginning of summer for each year 2016 and 2017.

1. The first campaign was realized on 27th and 28th July 2016 by covering the entire site by 17 sections made up of 384 points with $\mathrm{X}, \mathrm{Y}$ and $\mathrm{Z}$ coordinate. Extending over an area of $5 \mathrm{~km}$ with a length of 427 meters and a width varies between 37 and 258 meters.

2. The second campaign was carried out on 12th and 13th May 2017, covering the same area by 17 sections made up of 431 points with $\mathrm{X}, \mathrm{Y}$ and $\mathrm{Z}$ coordinate.

\subsection{Methods}

The climatic data used in this study were obtained from three gauging stations operated by the Hydraulic Basin Agency of Oum Er Rbia which also kindly provided information on the status of Bin El Ouidane dam. Based on the knowledge of the field work we applied an observation approach for achieving the main objectives. This approach aims to realize several cross sections throughout El abid river and near to Bin El Ouidane dam during 2016 and 2017. The creation of cross sections with topographic station is a technique used today to estimate soil erosion. This technique aims to integrate topographic and hydrographic data in the analysis of water erosion phenomena. The choice of this method will allow us to carry out cross sections covering approximately $180 \mathrm{~m}$ downstream of $\mathrm{El}$ Abid river, and about $3 \mathrm{~km}$ from Bin El Ouidane lake.

\section{Results and Discussion}

The results analysis of the applied approach shows that there are two key elements in the topographic data processing which allow to overcome the constraints of this application: the preparation of the field (number and distribution of the sections); calibration of systematic errors resulting from the superposition of topographic sections (by deformation correction and auto-calibration). An adequate combination of these elements allowed to obtain the accurate data, and more hydrographic coherent detail of the cross sections (a minimum error).

\subsection{Hydrological Response of El Abid River}

In arid and semi-arid areas, rainfall is often characterized by a strong spatial and temporal variability [19]. In this context from semi-arid to arid nature of its climate, Morocco is exposed, like all the Mediterranean countries to flush floods and inundations, which can be very damaging for public and private infrastructure, and cause many victims and also play an important role in river dynamic [20]. Located in the High Central Atlas (Morocco) El Abid river is one of the most important Moroccan tributaries that raised in a remarkable way. the frequency and intensity of floods in recent decades have grown in an exceptional way, especially in El Abid river, 
due to heavy rain intensity, land use variation and rugged topography characterize by high slope [21, 22]. Figure 3 shows the annual mean values of rainfall and discharge at Ait Ouchene gauging station which is located about $38 \mathrm{~km}$ from the upperpart of Bin El Ouidane dam. At annual scale, the long hydrological years recorded for the El Abid river (19702017) at the representative gauging station demonstrate that El Abid river shows a strong annual and seasonal variability in rainfall $(\mathrm{p} \mathrm{mm})$ discharge $\left(\mathrm{Qm}^{3} / \mathrm{s}\right)$ with winter and spring periods typically representing about $87 \%$ of flow (figure 3 ).
The annual rainfall varies from $711 \mathrm{~mm}$ as Max. and $199 \mathrm{~mm}$ as Min. with a mean of $415 \mathrm{~mm}$. The snow-rainfall hydrological regime can be divided into two periods. The wet winter-spring season lasts from December to May when average monthly precipitation can reach $80 \mathrm{~mm}$, with average monthly temperatures varying between $10^{\circ} \mathrm{C}$ and $17^{\circ} \mathrm{C}$. The dry season lasts from June to October with an average monthly precipitation not exceeding $5 \mathrm{~mm}$ and average monthly temperatures between $17^{\circ} \mathrm{C}$ to $28^{\circ} \mathrm{C}$ (figure $3,[23,24]$ ).

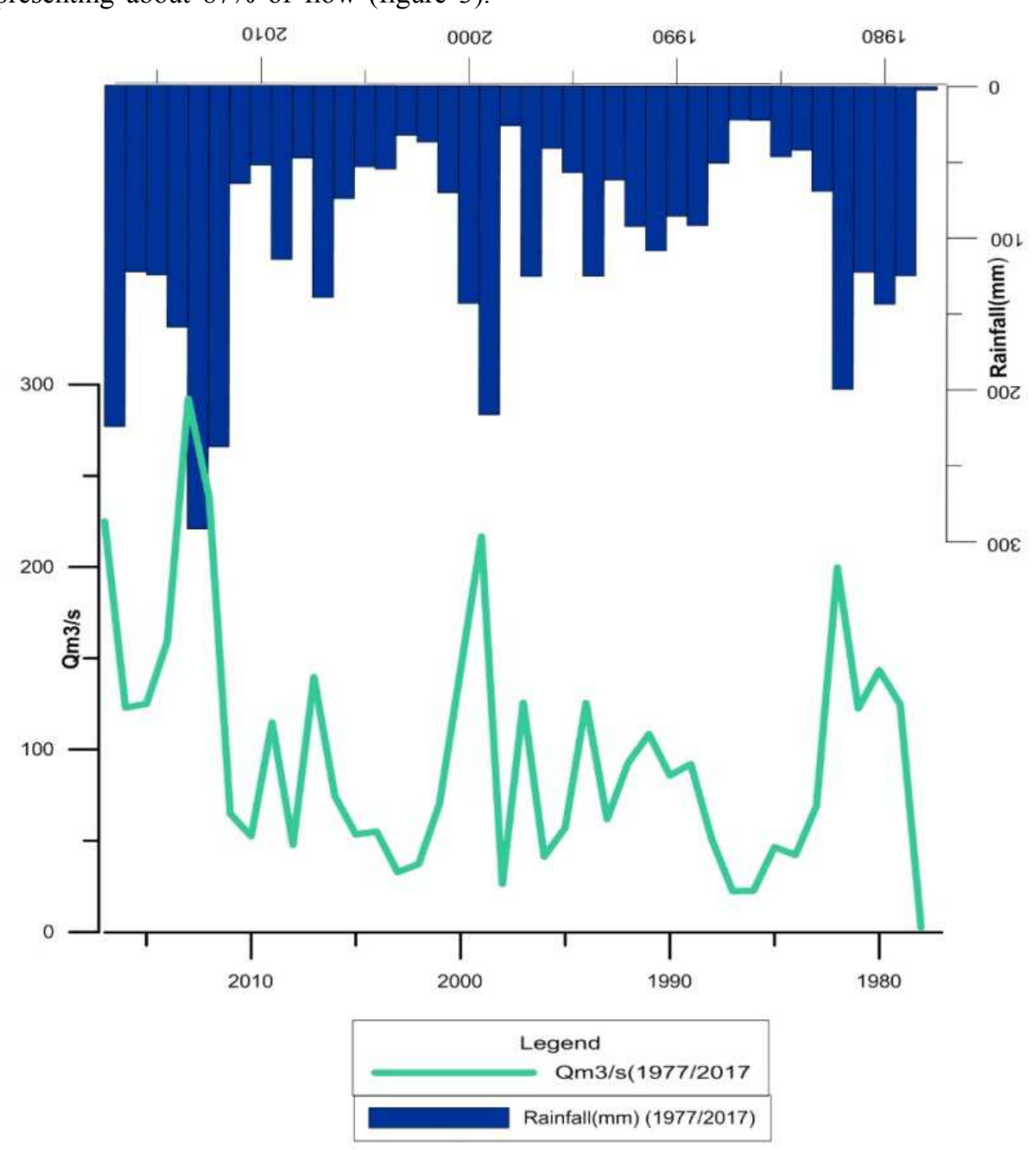

Figure 3. Annual time series of rainfall for Long term (1977-2017) Blue line show annual discharge Qm3/s at Ait Ouchene Gauging Station (ABHOER 2017).

\section{Rainfall-Runoff Relationships}

In Mediterranean mountain regions, the combination of high seasonality of the climate and the generally high spatial heterogeneity of the landscape increases dramatically the non-linearity of the rainfall-runoff relationship [25-27]. The main purpose of this section is to assess the hydrological response of El Abid river basing on relationships between rainfall-runoff at annual scale in order to understand the El Abid dynamic. El Abid river characterize by a high fluvial dynamic due to irregular nature of hydrological events. The response of this river is very quick. During the studied year (2016/2017) 26 events were occurred at El Abid river (figure 3 ) and contributed to fluvial dynamic. During dry conditions,
El Abid river responded quickly to rain events and declined rapidly after the rain stopped. While during wet conditions, the response vary with topography, soil properties and rainfall characteristics.

\subsection{Campaigns of 2016: Extraction of River Dynamic}

The companions of 2016 show a current fluvial dynamic of the studied section on 27th and 28th of July 2016, presenting certain remarkable characteristics of stream flow variables (Width, depth, wet section, slope...) This area constitutes a large horizontal plane of sediment deposing received from El Abid river. The characteristics of the 
sections at 2016 can be distinguished as follows:

1. An altitude average of 815 meters.

2. A relatively flat topography.

3. A depth average of the wet bed reaches to 2.30 meters.

4. A width average of section of 20 meters.
5. A length of the entire profile reaches to 250 meters.

6. A large banks exceed 240 meters and less than $1 \%$ of moderate slope

The variation of these characteristics also influences the current fluvial dynamics at the studied section.

Table 1. Presentation of cross sections in July 2016.

\begin{tabular}{|c|c|c|c|c|c|c|c|}
\hline \multicolumn{4}{|c|}{ Cross sections at 2016} & \multicolumn{4}{|c|}{ Characteristics of the cross sections } \\
\hline Number & $\mathbf{X}$ & $\mathbf{Y}$ & $\mathbf{Z}$ & Width (m) & Depth (m) & Wet sections (m) & Slope Line water (\%) \\
\hline P1-2016 & 32.44 & -6.29 & 818 & 21 & 2.50 & 3.20 & 1 \\
\hline P2-2016 & 32.44 & -6.29 & 817 & 20 & 2.79 & 4.90 & 1.52 \\
\hline P3-2016 & 32.44 & 6.25 & 818 & 21 & 2.78 & 4.20 & 2 \\
\hline P4-2016 & 32.43 & -6.25 & 818 & 31 & 2.50 & 4.11 & 1.20 \\
\hline P5-2016 & 32.43 & -6.24 & 819 & 22 & 2.80 & 4.10 & 1 \\
\hline P6-2016 & 32.43 & -6.25 & 819 & 19 & 2.82 & 4.12 & 1.23 \\
\hline P7-2016 & 32.43 & -6.25 & 820 & 16 & 2.95 & 4.18 & 1.90 \\
\hline P8-2016 & 32.44 & -6.25 & 819 & 18 & 2.93 & 3.20 & 1.29 \\
\hline P9-2016 & 32.43 & -6.25 & 816 & 12 & 2.90 & 3.18 & 1.20 \\
\hline P10-2016 & 32.42 & -6.26 & 819 & 16 & 2.25 & 3.16 & 1.22 \\
\hline P11-2016 & 32.42 & -6.27 & 816 & 17 & 2.23 & 3.01 & 1.24 \\
\hline P12-2016 & 32.43 & -6.28 & 813 & 17 & 2.15 & 2.98 & 1.23 \\
\hline P13-2016 & 32.44 & 6.29 & 816 & 15 & 2.11 & 2.89 & 1.25 \\
\hline P14-2016 & 32.42 & -6.28 & 816 & 15 & 1.95 & 2.78 & 1.52 \\
\hline P15-2016 & 32.41 & -6.27 & 819 & 14 & 1.96 & 2.79 & 1.22 \\
\hline P16-2016 & 32.41 & -6.28 & 819 & 12 & 1.98 & 2.50 & 1.02 \\
\hline P17-2016 & 32.41 & -6.27 & 818 & 11 & 2.20 & 2.18 & 1.02 \\
\hline
\end{tabular}

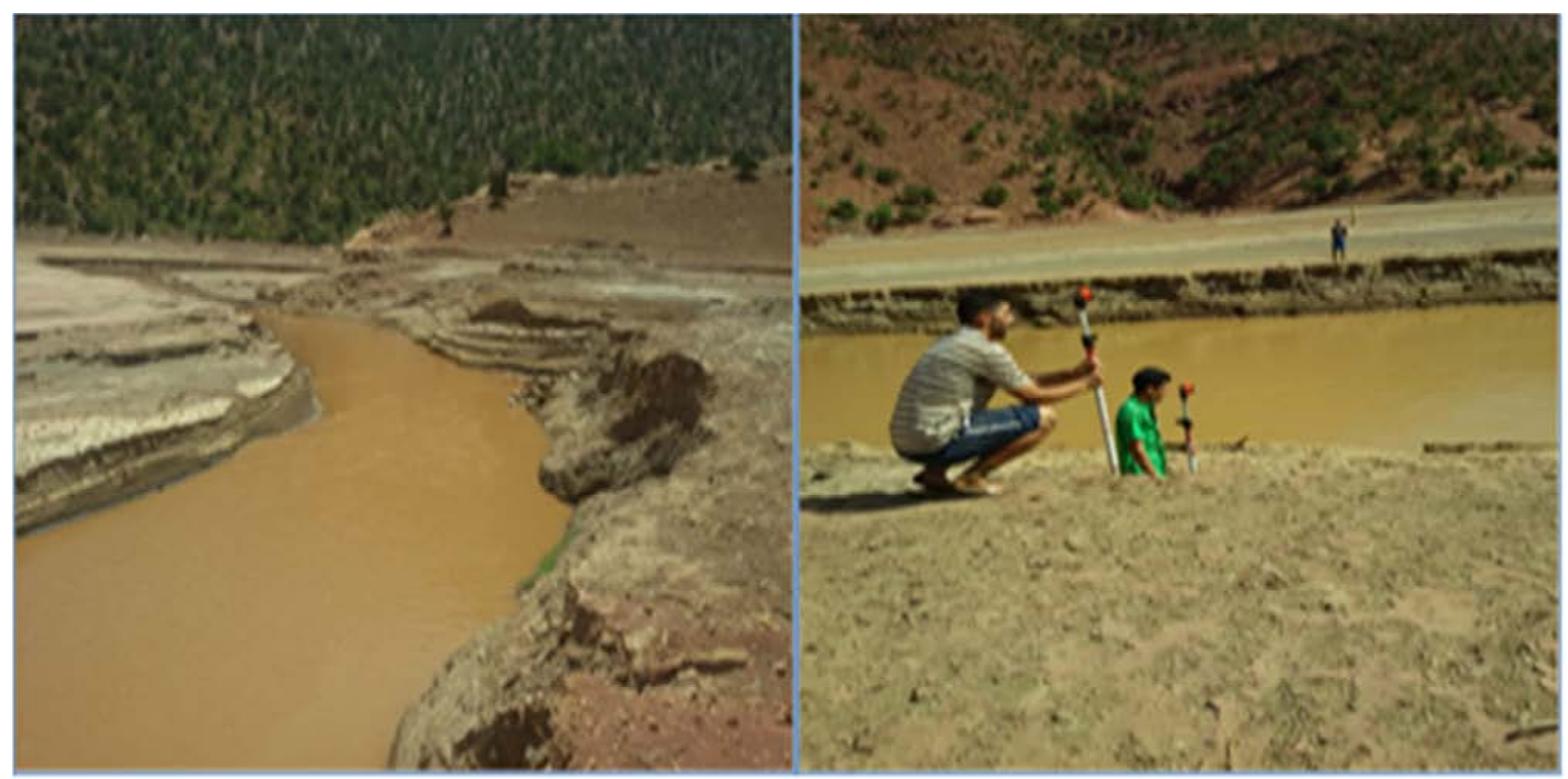

Figure 4. Realizing of cross sections / companion at july 2016.

The description results of 2016 campaign lead to understand the issue of fluvial dynamics at the section scale. The interpretation of this results leads to the assumption that any river has a wide response to hydrodynamic variables, with the purpose of modeling its morphology according to the fluctuations of the liquid and solid flows, as well as possible that others variables may evaluated.

\subsection{Cross-sections Campaigns of May 2017: Presentation and Analysis}

During the 2017 campaign, the topographic sections correspond to the same ones chosen for the previous campaign at 2016. The results already produced should contribute to better understanding of El Abid dynamic. As a result, this better understanding of riverbed dynamic contributes to facilitate the management actions, protection or even restoration actions for 
the hydro-system. The obtained results are presented in the table below (Table 2).
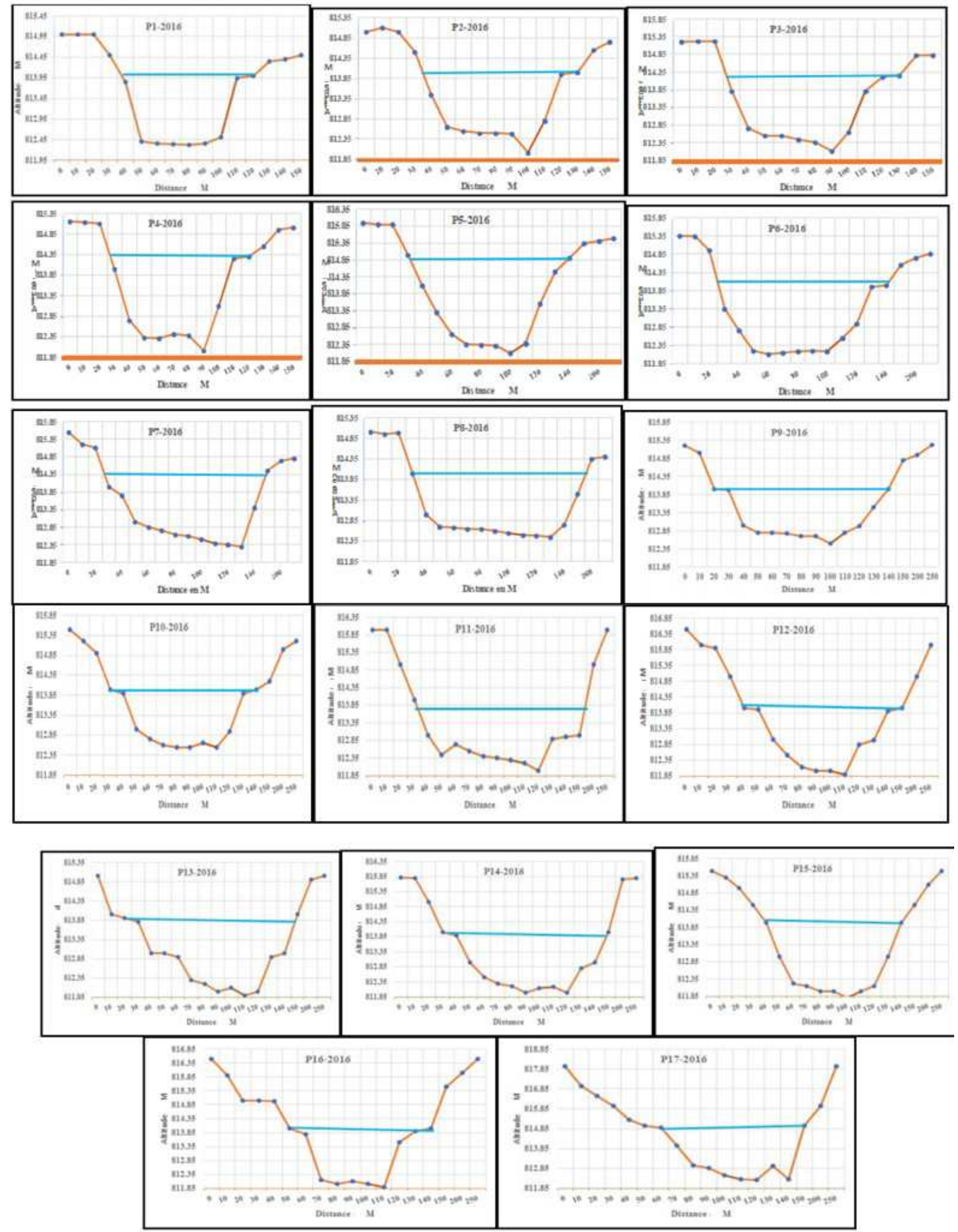

Figure 5. Presentation of cross profiles at July 2016 campaign. 


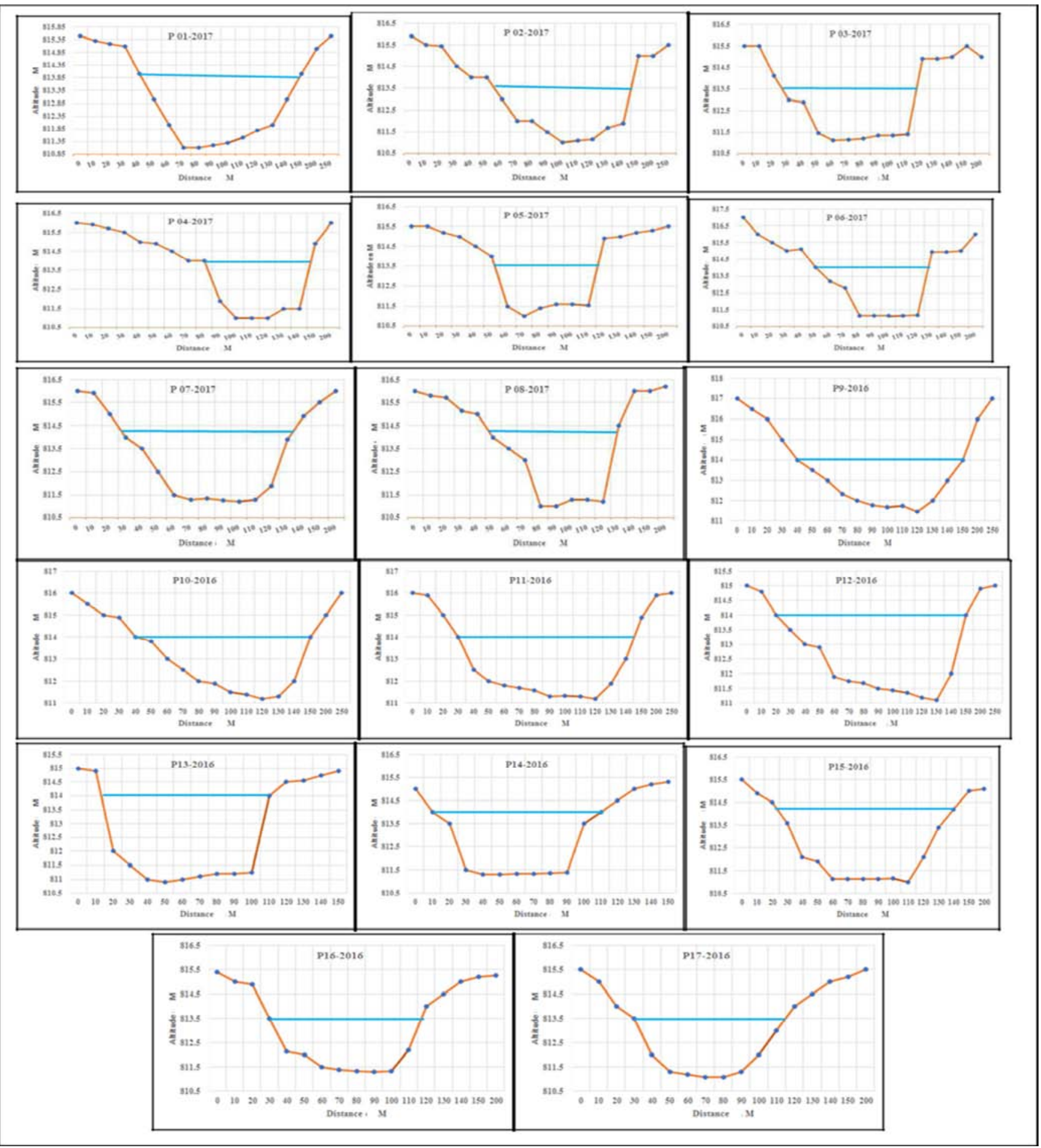

Figure 6. Presentation of cross profiles at July 2016 campaign.

The obtained results showed a good connection between the minor and major bed of El Abid river at the upstream part of Bin El Ouidane dam, which gives an overview about the actual circumstances of rivers in the arid and semi-arid regions. Overall, from the upstream to downstream part of the study area, an apparent evolution has registered. These generally exhibit a greater or lesser resistance to change (determined by floods or anthropogenic actions). Whether very active beds are stable or not, evolving or mobile beds that can thus be defined, occupy sections of watercourse of varying lengths. 
Table 2. Presentation of cross sections at Mai 2017.

\begin{tabular}{llllllll}
\hline \multicolumn{2}{l}{ Cross sections at 2017 } & \multicolumn{5}{l}{ Characteristics of the cross sections } \\
\hline Number & $\mathbf{X}$ & $\mathbf{Y}$ & $\mathbf{Z}$ & Widths $(\mathbf{m})$ & Depth $(\mathbf{m})$ & Wet sections (m) & Slope Line water (\%) \\
\hline P1-2017 & 32.43 & -6.29 & 819 & $23 \mathrm{~m}$ & $2.90 \mathrm{~m}$ & 4 & 1 \\
P2-2017 & 32.44 & -6.29 & 818 & 22.50 & 3.50 & 5.2 & 1.60 \\
P3-2017 & 32.44 & 6.28 & 819 & 22 & 3.75 & 4.90 & 2.10 \\
P4-2017 & 32.43 & -6.28 & 819 & 31.5 & 2.95 & 4.95 & 1.25 \\
P5-2017 & 32.44 & -6.27 & 818 & 23 & 3.15 & 4.1 & 1.10 \\
P6-2017 & 32.43 & -6.27 & 818 & 20 & 2.98 & 4.88 & 1.20 \\
P7-2017 & 32.42 & -6.26 & 819 & 17 & 3.12 & 4.75 & 1.95 \\
P8-2017 & 32.43 & -6.26 & 817 & 19 & 3.30 & 3.85 & 1.35 \\
P9-2017 & 32.44 & -6.26 & 816 & 14 & 3.75 & 4.2 & 1.45 \\
P10-2017 & 32.43 & -6.26 & 816 & 16.5 & 2.97 & 3.9 & 1.37 \\
P11-2017 & 32.43 & -6.28 & 817 & 18 & 3.02 & 3.2 & 1.45 \\
P12-2017 & 32.43 & -6.28 & 813 & 17.5 & 2.94 & 3.25 & 1.55 \\
P13-2017 & 32.44 & 6.29 & 816 & 16 & 3.16 & 3.45 & 1.65 \\
P14-2017 & 32.42 & -6.29 & 816 & 16.5 & 2.78 & 3.15 & 1.71 \\
P15-2017 & 32.41 & -6.27 & 819 & 16 & 2.50 & 2.90 & 1.25 \\
P16-2017 & 32.42 & -6.28 & 819 & 17 & 2.78 & 3.33 & 1.32 \\
P17-2017 & 32.42 & -6.27 & 818 & 14 & 2.96 & 1.15 \\
\hline
\end{tabular}

\subsection{Discussion the Comparison Between the Cross Sections During the Two Campaigns 2016 and 2017}

The objective of this analysis is to highlight the river dynamic that occurred at annual scale based on the comparison of the cross sections during 2016 and 2017. Within the table 1, the first profiles figures taken at 2016 showed a clear contrast similar to those recent profiles at 2017, which allowed and give the possibility to evaluate a certain number of geometrical characteristics as slopes, wet sections and also to determine an equilibrium of the riverbed at the studied sections of Oued El Abid. The presented results reveal a representative characteristic of the riverbed which can be used to calculate the hydraulic parameters in order to establish the link with the river morphologies.

Basing on the comparison between the profiles of 2016 and 2017 the results are diverse. From the upstream to downstream part, the stable and unstable beds are assembled in various manner at the studied section, this instability is affected by the characteristics of the alluvial bottoms linked to the regional and local circumstances.

The velocity of this evolution is very variable. It can be noted that between 2016 and 2017 the river dynamic is accelerated from a low to very strong state. In 2016 campaign a significant change detected at El Abid river dynamic, while the level acceleration of river dynamic was largely increased in the same section at 2017. Besides, from upstream to downstream part there is an important difference of the riverbed bottom at El Abid river. Consequently, the clear variations of shape and size of the studied sections during the monitoring period (2016-2017) confirm a strong fluvial dynamic. As a result, the profiles sections made at the different campaigns showed an incision in term of bed. This phenomenon is mainly represented by the processes of erosion and deposit at El Abid River; which affect the Bin El Ouidane dam by the siltation, phenomenon especially during the humid seasons.

\subsubsection{The width Evolution of El Abid River Section (2016/2017)}

The evolution of the width at the studied sections is presented in figure 6 . Based on the comparison of the two companions at 2016 and 2017; the width of the riverbed has been clearly modified, this confirms a short time of concentration to fluvial dynamic within El Abid river.

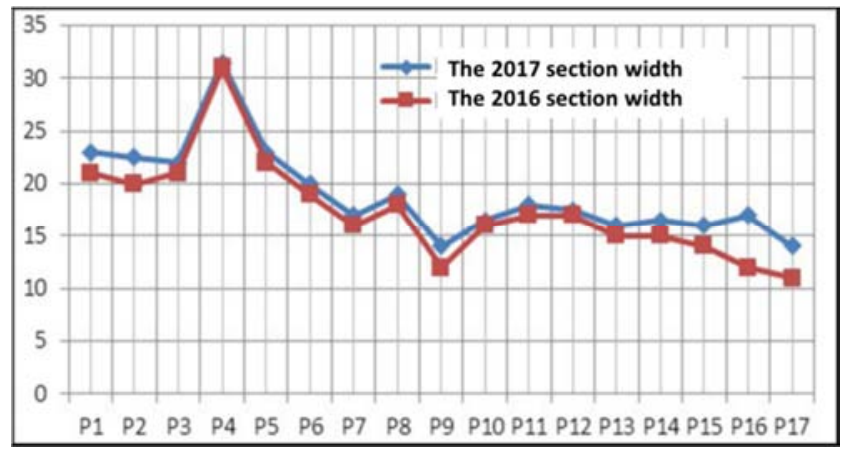

Figure 7. Comparison between sections width at 2016 and 2017.

The evolution of the width at the studied section can be classified to two parts, regarding the difference of the width varies between $0.05 \mathrm{~cm}$ and $5 \mathrm{~m}$. The instability of the fluvial landscape is affected by the floods, events and flash floods which influence negatively Bin El Ouidane dam. The filling of the dam pushes water towards the studied section which quickly contribute to sediment deposition. Moreover, the studied section, considered as a flood zone, the reduction of the superficial slope of water and velocity cause the abandonment of the suspended sediment load. At this state, the deposits are made by the fall of the fine particles especially suspended sediment transport. The dynamic of the studied section can be explained by the sedimentation in the riverbed and the vegetation growth at the banks which is an 
obstacle of the sedimentation. consequently, this evolution of riverbed is inscribed in the formation of the wet sections.

Table 3. Comparison between the profiles of the campaigns 2016 and 2017.

\begin{tabular}{|c|c|c|c|c|}
\hline Number & Width & depth & Wet section & Line slopes water in \% \\
\hline P1-2016 & $21 \mathrm{~m}$ & $2.50 \mathrm{~m}$ & 3.20 & 1 \\
\hline P1-2017 & $23 \mathrm{~m}$ & $2.90 \mathrm{~m}$ & 4 & 1 \\
\hline Comparison & 2 & 0.4 & 0.23 & 0 \\
\hline P2-2016 & 20 & 2.79 & 4.90 & 1.52 \\
\hline P2-2017 & 22.50 & 3.50 & 5.2 & 1.60 \\
\hline Comparison & 2.5 & 0.71 & - & 0.08 \\
\hline P3-2016 & 21 & 2.78 & 4.20 & 2 \\
\hline P3-2017 & 22 & 3.75 & 4.90 & 2.10 \\
\hline Comparison & 1 & 0.97 & - & 0.10 \\
\hline P4-2016 & 31 & 2.50 & 4.11 & 1.20 \\
\hline P4-2017 & 31.5 & 2.95 & 4.95 & 1.25 \\
\hline Comparison & 0.5 & 0.45 & - & 0.05 \\
\hline P5-2016 & 22 & 2.80 & 4.10 & 1 \\
\hline P5-2017 & 23 & 3.15 & 4.75 & 1.10 \\
\hline Comparison & 1 & 0.35 & - & 0.10 \\
\hline P6-2016 & 19 & 2.82 & 4.12 & 1.23 \\
\hline P6-2017 & 20 & 2.98 & 4.88 & 1.20 \\
\hline Comparison & 1 & 0.16 & - & 0.03 \\
\hline P7-2016 & 16 & 2.95 & 4.18 & 1.90 \\
\hline P7-2017 & 17 & 3.12 & 4.75 & 1.95 \\
\hline Comparison & 1 & 0.17 & - & 0.05 \\
\hline P8-2016 & 18 & 2.93 & 3.20 & 1.29 \\
\hline P8-2017 & 19 & 3.30 & 3.85 & 1.35 \\
\hline Comparison & 1 & 0.37 & - & 0.06 \\
\hline P9-2016 & 16.5 & 2.85 & 3.16 & 1.37 \\
\hline P9-2017 & 14 & 3.75 & 4.2 & 1.45 \\
\hline Comparison & 2.5 & 0.9 & 0.02 & 0.08 \\
\hline P10-2016 & 16 & 2.25 & 3.16 & 1.22 \\
\hline P10-2017 & 16.5 & 2.97 & 3.90 & 1.37 \\
\hline Comparison & 0.05 & 0.72 & - & 0.15 \\
\hline P11-2016 & 17 & 2.23 & 3.01 & 1.24 \\
\hline P11-2017 & 18 & 3.02 & 4.2 & 1.45 \\
\hline Comparison & 1 & 0.79 & - & 0.03 \\
\hline P12-2016 & 17 & 2.15 & 2.98 & 1.23 \\
\hline P12-2017 & 17.5 & 2.94 & 3.1 & 1.55 \\
\hline Comparison & 0.5 & 0.79 & - & 0.4 \\
\hline P13-2016 & 15 & 2.11 & 2.89 & 1.25 \\
\hline P13-2017 & 16 & 3.16 & 3.25 & 1.65 \\
\hline Comparison & 1 & 1.05 & - & 0.4 \\
\hline P14-2016 & 15 & 1.95 & 2.78 & 1.52 \\
\hline P14-2017 & 16.5 & 2.78 & 3.45 & 1.71 \\
\hline Comparison & 1.05 & 0.83 & - & 0.19 \\
\hline P15-2016 & 14 & 1.96 & 2.79 & 1.22 \\
\hline P15-2017 & 16 & 2.50 & 3.15 & 1.25 \\
\hline Comparison & 2 & 0.54 & - & 0.03 \\
\hline Comparison & 5 & 0.8 & - & 0.3 \\
\hline P17-2016 & 11 & 2.20 & 2.18 & 1.02 \\
\hline P17-2017 & 14 & 2.96 & 3.33 & 1.15 \\
\hline Comparison & 3 & 0.76 & - & 0.13 \\
\hline
\end{tabular}

\subsubsection{The Depth Evolution of El Abid Section (2016-2017)}

The evolution of depth is fundamental, for the understanding of the flush floods movement and their amount of sediment loads which transport through in the major beds [24] The difference between the depths of the cross sections of the year 2016 and 2017 is moderately evolving.

From upstream to downstream part, the depth variations range between $0.16 \mathrm{~cm}$ and $1.05 \mathrm{~m}$. As a result, this number confirms a strong dynamic and therefore a greater fragility in terms of resistance to runoff. It is therefore logical that the movement of suspended sediment is the important dynamic, which is shown at this section. So, this area is considered as a deposit zone and at the same time a zone of transfer sediments towards Bin El Ouidane dam. Indeed, the vertical dynamic and the incision of El Abid river has largely coincided with the emergence of flush floods.

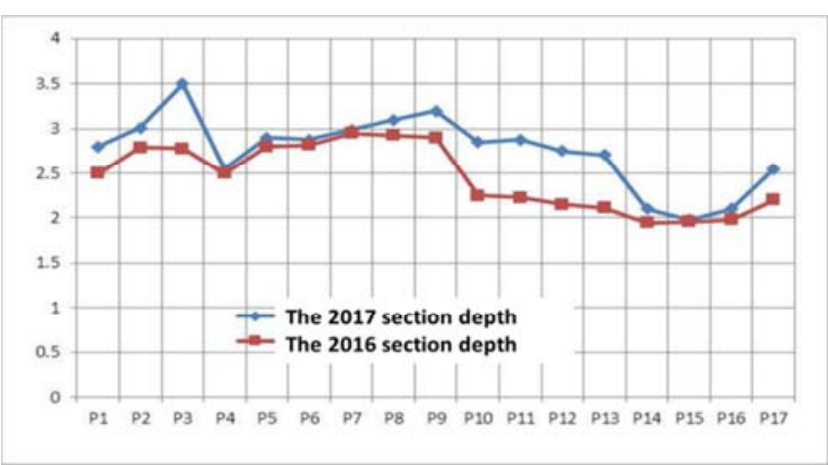

Figure 8. Comparison between sections depth at 2016 and 2017.

\subsubsection{Evolution of the Wet Section at El Abid River (2016/2017)}

The wet sections at the studied profile have a large area generally greater than $2 \mathrm{~m}$. From one section to another, there is a high variability. The smallest variations are found in the downstream part of the section, while the highest wet sections are located toward upstream part. Thus, there are sometimes a significant contrast over short distances; the largest sections exceed $5 \mathrm{~m}$. It can be noted also that this dynamic influenced by the natural conditions and the adjustments of the riverbed that affect the rising of the water level at Bin El Ouidane dam. the dimension variation of the wet sections constitutes a good indicator to estimate the fluvial dynamic of El Abid river (figure 9).

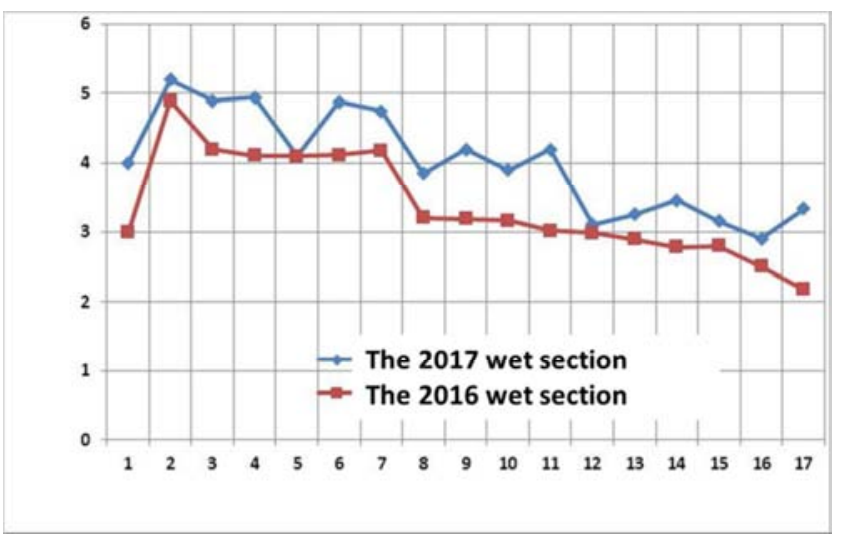

Figure 9. Comparison between wet sections at 2016 and 2017.

Overall, the capacity of the wet sections of El Abid river is not sufficient to accommodate the quantity of flow during the flush flood, subsequently water overflows in the riverbanks and in the major bed. However, where the banks are lowest and the largest wet sections, water is overflown, and the suspended sediment is placed in the form of lateral benches. The superposition of the old and recent profiles in the studied section indicates how the shapes of the minor bed have 
changed at year scale. In this context; the comparison of the wet sections of the cross profiles at two companions during 2016 and 2017 is showed that the dynamic was clear at 2017. Finally, except for a few profiles, the geometric characteristics of the studied section at downstream part of El Abid river have clearly changed. The biggest differences in the shape of the wet sections are linked to the rising of the water at Bine El Ouidane dam (anthropogenic actions) than to the adjustment of the river. Thus, El Abid river is modified and influenced by anthropogenic activities.

\subsubsection{Evolution of the Line Slope Water at the Section of El Abid River (2016 / 2017)}

The analysis of line slope water evolution at the section studied between two companions during 2016 and 2017 shows that the results are contradictory. In more detail, the differences are not negligible. Particularly the very significant difference was in the upstream part of the section (profiles 9, 10, 11, 12, 13, 1416 and 17), while in the downstream part this difference -was very small to zero.

The explanation for this large difference can be further justified by the effect of the Bin El Ouidane dam, which influences discharge and deposits in the downstream part of El Abid river (figure 10).

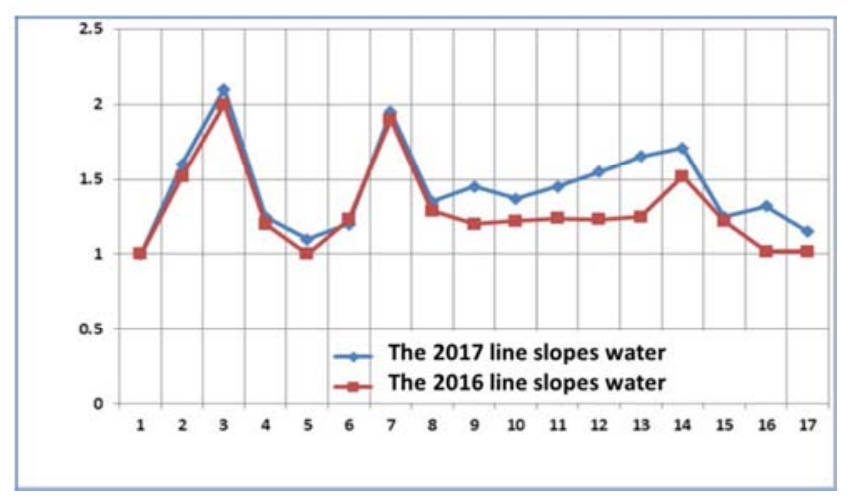

Figure 10. Comparison between line slope water at 2016 and 2017.

Finally, topographic surveys show that El Abid riverbed has an irregular shape. It includes riverbanks of fine alluvium, often vegetated or surmounted by flow. The slope of the water varies according to the flow velocity.

\subsection{Characterization of Fluvial Dynamic at the Studied Section of El Abid River (2016 and 2017)}

According to the comparison between the response variables (width / depth), the studied section has a strong lateral dynamic as well as a vertical evolution in the different sections. Erosion mechanisms are much more frequent in this section. Depending the presented results above showed that the studied section during two years revealed a significant dynamic, this means that this section is a deposit zone and a transport area at the same time, but according to the discharge energy of El Abid river.

The evolution of the channel shape (width / depth) at annual scale allowed to characterize a strong dynamic of the depth, width, and wet section of the studied section near to Bin El Ouidane dam. These results clearly suggest a rapid pattern towards morphological readjustments of El Abid river which therefore shows a permanent dynamic during the flush flood.

This strong erosion is combined with a progressive dynamic of the riverbanks, which effect on changing the dynamic after the period of flush flood. obviously, according to the two topographical surveys 2016/2017, the erosion of the banks resulting from the passage of the flush flood is directly involved in a strong destabilization. As a result, the comparison between the two companions allowed to estimate the morpho-dynamic response of the sections to the discharge during the events periods.

Consequently, the erosion dynamic contributes to the silting of Bin El Ouidane dam, which threatens its storage capacity and its duration of surviving (table 4).

Table 4. Comparison between width / depth in cross sections 2016 and 2017

\begin{tabular}{llll}
\hline Number of cross section & Width (m) & Depth (m) & Type of dynamic \\
\hline P1- 2016-2017 & 2 & 04 & Lateral \\
P2-2016-2017 & 2.5 & 0.71 & Vertical (incision) \\
P3-2016-2017 & 1 & 0.97 & Lateral \\
P4-2016-2017 & 0.5 & 0.45 & Vertical (incision) \\
P5-2016-2017 & 1 & 0.35 & Lateral \\
P6-2016-2017 & 1 & 0.16 & Lateral \\
P7-2016-2017 & 0.79 & 0.87 & Vertical (incision) \\
P8-2016-2017 & 1 & 0.37 & Lateral \\
P9-2016-2017 & 2.5 & 0.9 & Lateral \\
P10-2016-2017 & 0.05 & 0.72 & Vertical (incision) \\
P11-2016-2017 & 0.76 & 0.79 & Vertical (incision) \\
P12-2016+-2017 & 0.5 & 0.79 & Vertical (incision) \\
P13-2016-2017 & 1 & 1.05 & Vertical (incision) \\
P14-2016-2017 & 1.05 & 0.83 & Lateral \\
P15-2016-2017 & 2 & 0.54 & Lateral \\
P16-2016-2017 & 5 & 0.8 & Lateral \\
P17-2016-2017 & 3 & 0.76 & Lateral \\
\hline
\end{tabular}

\section{Conclusion}

Thus, any river erodes, transports and deposits suspension and solid materials detached from the upstream part to downstream part of the catchment scale. The erosion phenomena and deposits process at El Abid basin participate in its morphological readjustments. Riverbeds are adjustable areas to optimize water and sediment transfers, the bottom load playing a crucial role in river dynamic. Consequently, El Abid river, is not a stable river in term of flow type. Because, it is playing an important role in eroding, accelerating and deposing the sediment at the outlet near to the Bin El Ouidane dam. It also evolves over time the river dynamics that accelerate these phenomena which can negatively affect land uses.

In this case, El Abid river is a representative model of the rivers in Central High Atlas Mountains in Morocco, which known by the aggressiveness of its climate, and its sensitivity to the phenomena of erosion, particularly very dynamic in the Mountain zones. This area is characterized by irregular rainfall patterns which have a considerable influence on soil losses. Under these conditions, El Abid basin, with its mountainous characteristics, the agricultural land and the villages that populate it, appears very vulnerable. Especially 
the downstream part of the basin, Bin El Ouidane dam suffers from siltation linked to significant erosion. Each year, significant quantities of sediment are deposited at the bottom of this reservoir.

\section{Competing Interests}

The authors declare that they have no known competing financial interests or personal relationships which have, or could be perceived to have, influenced the work reported in this article.

\section{Acknowledgements}

The authors thank the reviewer Ftom El Houari for their useful comments which helped to improve the overall quality of the manuscript and Jamal Ouakhir for his help during the field work.

\section{References}

[1] Tadrist. N, Debauche. O, Boualem. R, Dimitri. X (2016): Impact de l'érosion sur l'envasement des barrages, la recharge des nappes phréatiques côtières et les intrusions marines dans la zone semi-aride méditerranéenne: cas du barrage de Boukourdane

(Algérie).http://hdl.handle.net/2268/203492.20p.

[2] Lal. R, (1998): Soil Erosion Impact on Agronomic Productivity and Environment Quality: Critical Reviews. Plant Sciences, 17, 319-464.

[3] Parveen. R, Kumar. U, (2012): Integrated Approach of Universal Soil Loss Equation (USLE) and Geographical Information System (GIS) for Soil Loss Risk Assessment in Upper South Koel Basin, Jharkhand. Journal of Geographic Information System, 4, 588-596. http://dx.doi.org/10.4236/jgis.2012.46061.

[4] Apusiga Adongo. T, Kugbe. J. X. Gbedzi, V. D, (2014): Siltation of the Reservoir of Vea Irrigation Dam in the Bongo District of the Upper East Region, Ghana. International Journal of Science and Technology, 4, 2224-3577.

[5] Chevalier. J. J, Pouliot. J, Thomson, Boussema. M. R, (1995): Systèmes d'Aide à la Planification Pour la Conservation des Eaux et des Sols (Tunisie). Systèmes d'Information Géographique Utilisant les Données de Télédétection. Actes du colloque scientifique international, Hammamet, Tunisie, 12 Novembre 1994, 4-12.

[6] Lahlou. A, (1977): Specific Degradation of Watershed in Morocco. Report $\mathrm{n}^{\circ} 1000$, Ministry of Equipment and National Promotion, Water Direction, Exploitation Division, Water Management Service, Rabat, 15-17.

[7] Ait Fora. A, (1995): Modélisation Spatiale de l'Erosion Hydrique dans un Bassin Versant du Rif Marocain: Validation de l'Approche Géomatique par la Sédimentologie, les Traceurs Radio-Actifs et la Susceptibilité Magnétique des Sédiments. PhD Thesis, Sherbrooke University, Quebec, 162-192.

[8] Mhirit. O, Benchekroun. F, (2006): Les Ecosystèmes Forestiers Marocains: Situation, Enjeux et Perspectives Pour 2025. Rapport sur le Développement Humain au Maroc,
Rabat, 7, 13-17.

[9] Tahri, M., Merzouk, A., Lamb, H. F. and Maxted, R. W. (1993): Etude de l'Erosion Hydrique dans le Plateau d'Imelchil dans le Haut Atlas Central. Utilisation d'un SIG. Geo Observateur, 3, 51-60.

[10] Merzouki, T. (1992) Diagnostic de l'envasement des grands barrages marocains. Revue marocaine du génie civil, 38, 4650 .

[11] Lahlou. A, (1990): Envasement du barrage Mohamed Ben Abdelkrim Al Khattabi et lutte anti-erosive du bassin versant montagneux situe à l'amont. Administration de l'Hydraulique, Avenue Hassan BEN Chekroune, RABAT, MAROC194, 243252.

[12] Ouakhir. H, El Ghachi. M, (2015): L'impact des lâchés du barrage de Bin el Ouidane sur l'aval du bassin Oued El Abid: Inondations anthropiques et cartographie (bassin Oum ErrBia - Maroc). PFE 2015. FLSHBM. 262P.

[13] Missenard. y, (2006): le relief des atlas marocains: contribution des processus asthénosphériques et du raccourcissement crustal, aspects chronologiques. 225p.

[14] Leveque. P, (1952): Géologie Appliquée aux Grands Travaux du Maroc (Zone française). Fascicule I. Les aménagements de l'Oued el Abid. Published by XIX Congres Géologique International Monographies Régionales, 3 Serie, Maroc No. 5, 1952, 165 pages.

[15] Legates. d. Willmot. c, (1990): mean seasonal and spatial variability in global surface air temperature, theor. appl. climatol., vol 41, pp11-21.

[16] Souhel. A, El Bchari. F, (2011): Haut Atlas Central, Partie Nord-Ouest, North-western Central High Atlas, éditions du service géologique du Maroc-rabat. p306.

[17] Alaoui. M, Housni. F, Najine. A, Bracamontesdel. H, \& Wafik. A, (2017): Impact of Climate Change on the Landslide in the Central High Atlas of Morocco: Case of Tit N'Ziza, El Ksiba. International Journal of Advanced Research, 5 (12), 584-592. https://doi.org/10.21474/ijar01/5996.

[18] Morat, P., (1969): note sur l'application a Madagascar du quotient pluviothermique d'Emberger., pp 16-23.

[19] Ouatiki. H, Boudhar. A, Tramblay. Y, Jarlan. L, Benabdelouhab. T, Hanich. L, El Meslouhi. M. R, \& Chehbouni. A, (2017): Evaluation of TRMM 3B42 V7 rainfall product over the Oum Er Rbia watershed in Morocco. Climate, 5 (1), 1-17. https://doi.org/10.3390/cli5010001.

[20] Karaoui, I., Arioua, A., El Amrani Idrissi, A., Hssaisoune, M., Nouaim, W., Ait ouhamchich, kamal, \& Elhamdouni, D. (2018). Assessing land use/cover variation effects on flood intensity via hydraulic simulations. Geology, Ecology, and Landscapes, 2 (2), 73 https://doi.org/10.1080/24749508.2018.1452461.

[21] Vicente. S \& López J. (2005): Hydrological response to different time scales of climatological drought: An evaluation of the standardized precipitation index in a mountainous Mediterranean basin. Hydrology and Earth System Sciences, 9 (5), 523-533.10.5194/hess-9-523-2005.

[22] Cherifi. O, (2001): Apports du bassin versant et processus trophodynamiques du lac de Barrage de Bin El Ouidane (Maroc) 291p. Thèse de doctorat. Marrakech. 
[23] Cherifi. O, Loudiki. M. O, (2002): Impact of El Abid River Basin Loads on Water Quality of the Bin El Ouidane dam (Morocco). 22p.

[24] Latron. J, Llorens. P, \& Gallart. F, (2009): The hydrology of Mediterranean mountain areas. Geography Compass, 3 (6), 2045-2064. https://doi.org/10.1111/j.17498198.2009.00287.x.

[25] Carlo. L, (1991): Management of reservoirs, International Journal of Water Resources Development, 7:2, 117-123, DOI: 10.1080/07900629108722502.
[26] Filippo. G, Piero. L, (2008): Climate change projections for the Mediterranean region, Edited by Lionello Piero, Planton Serge, RodóXavier.

[27] Dinia. N, Chaoui. A, Bischof. R, (1998): Vidange du fond et évacuateur de crue du barrage a contreforts d'al massira sur l'Oum Er Rbia, Maroc. Pp 3-16. 